\title{
Ethical responsibilities of man toward animal world. The vision of Robert Spaemann ${ }^{*}$
}

\section{Etyczne zobowiązania człowieka wobec świata zwierząt. Wizja Roberta Spaemanna}

\author{
Józef Kożuchowski \\ WSB University in Gdańsk, Poland \\ ORCID: https://orcid.org/0000-0001-6769-1473• jozefkozuchowski@gmail.com
}

\begin{abstract}
The article presents the concept of moral obligations that man has towards animals proposed by Robert Spaemann. Spaemann give reasons for perceiving animal as an object of the law. His analyses present possibilities of solving basic moral questions like for example experiments on animals, animal husbandry, animal slaughter, hunting, interfering into animal's nature and our responsibility for them. Spaemann presents very original arguments for taking care of and responsibility for animals, deriving it from human dignity.
\end{abstract}

Keywords: animal ethics, person, Robert Spaemann, personalism

Streszczenie: W artykule przedstawiono zaproponowaną przez Roberta Spaemanna koncepcję zobowiązań moralnych człowieka wobec zwierząt. Spaemann podaje przyczyny postrzegania zwierzęcia jako przedmiotu prawa. Jego analizy przedstawiają możliwości rozwiązania podstawowych kwestii moralnych i ludzką odpowiedzialność za takie kwestie, jak np. eksperymenty na zwierzętach, hodowla i ubój zwierząt, polowanie oraz ingerowanie w naturę zwierząt. Spaemann przedstawia bardzo oryginalne argumenty za dbałością i odpowiedzialnością za zwierzęta, wyprowadzając te argumenty z ludzkiej godności.

Słowa kluczowe: etyka zwierząt, osoba, Robert Spaemann, personalizm

The animal world is not for our benefit, but for our joy. (Spaemann 2000, 465)

\section{Introduction}

Although the importance of analyses of the animal world in the philosophical and ethical aspect has been addressed since

\footnotetext{
" This article was originally published in Polish as Kożuchowski, Józef. 2011. "Etyczne zobowiązania człowieka wobec świata zwierząt. Wizja Roberta Spaemanna." Studia Ecologiae et Bioethicae 9(1): 29-48. The translation of the article into English was financed by the Ministry of Science and Higher Education of the Republic of Poland as part of the activities promoting science - Decision No. 676/P-DUN/2019 of 2 April 2019. Translation made by GROY Translations.
}

ancient philosophy, it is still momentous and relevant (Ślipko 2009, 55-58). There are numerous reasons for this, including the mass and at the same time repulsive method of animal husbandry, the insufficient perception of the issue of their suffering (of which there is too much), the conducting of experiments on these living creatures, which must be considered unnecessary (e.g. due to the needs of the cosmetics industry), the lack of due care for them in poor countries, and the destruction of animal species as a result of 
economic and military expansionist ambitions, which has never before been so widespread ${ }^{1}$.

Spaemann's investigation (which is respected regardless of his worldview and political affiliation) is already particularly valuable as it makes us aware of this type of animal situation. At the same time, it outlines methods of addressing all the most frequently raised issues in our ethical discussions concerning our approach to these beings. Therefore, not only the problem of breeding, experimentation, suffering, destruction of species but also the ontic status of animals, their so-called rights, the theme of protection, hunting, slaughter and responsibility.

In the reflections of the German philosopher, our attention is drawn to the fact that he resembles and recalls one of the basic concepts of Aristotelian theory namely the concept of life. Based on that - contrary to the popular view of modern philosophy, inspired and articulated by Descartes, (according to which, animals are devoid of soul belong to the world of matter), he stresses that an animal is not an object, but a living being, manifesting intentional aspirations and, like a man, possessing an interior covered with mystery (Tomasz z Akwinu 1985, 55).

At the same time, in contrast to the anthropological-ethical theories that exclude or challenge the existence of qualitative differences between the human and animal worlds, Spaemann originally justifies that a man is materially superior to an animal. It is characterized and distinguished by the ability to self-identify (the ability to place in the centre of attention, not himself, but another being), which an animal absolutely does not manifest.

\footnotetext{
${ }^{1}$ In view of this situation, the churches, as emphasised by the German Professor Ferdinand Krenzer, are seeking the protection of plant and animal species whose existence is under threat (as a result of promoting economic and military interests), to perceive the problem of animal suffering to a much greater extent, to ban the factory farming, to stop experiments on animals used in the production of cosmetics, cigarettes, alcohol and to expand the natural space (Krenzer 2000, 262-263).
}

We must also be interested in the original argument, formulated by the German philosopher, for the protection of animals. It is not the interest of a man and his needs that inspire this protection, for it has a fundamental source in human dignity (Spaemann 1993, 154).

Two primary sources constitute the presentation of below reflections: publications of the German philosopher (books and articles) and numerous interviews conducted with him by the author of the article in February and March 2011 (Spaemann 2011a; 2011b) ${ }^{2}$. The author of those analyses would also like to emphasise that they were accepted by Spaemann and claimed to be consistent with his intention.

\section{The place of animals in the hierarchy of beings and their specificity}

An animal, in the hierarchy of beings, occupies a middle part which is placed between beings with material and spiritual structure. An animal is neither an object nor a person, but a living being (Ingesiep, and Baranzke 2008, 11). Yes, there is some variation among animals, which allows us to talk about the hierarchy among those living beings. Another place within it belongs to, for example, monkeys, horses, dogs, elephants, as the so-called higher category animals, than to earthworms and mice (Ingesiep, and Baranzke 2008, 79; Spaemann 2011a). In general, however, the hierarchy within living beings, since it is a three-tier one, looks as follows: first human beings, then animals and finally plants (Krąpiec 1996, 253; Spaemann 2011b).

To answer the question what the nature of an animal is, from the perspective of metaphysics, one must state that it is sensual (Gilson 1960, 298; Spaemann 2011a). What distinguishes it from plants is that it has a sensual soul. ${ }^{3}$

${ }^{2}$ The contents of the interviews, recorded on cassette tapes and recorded in computer writing, are in the possession of the author of the article.

${ }^{3}$ Although, as the French philosopher points out, an animal as a purely sensory being is devoid of mind, it possesses, however, a kind of natural prudence and instinctive judgment, which constitutes a certain degree of participation in human understanding (Gilson 
While introducing the specificity of an animal in empirical language, it is necessary to indicate its abilities to the perception of a sensual nature. Among the latter, we should mention two most important ones: to perceive and to feel (experience) with pleasure and pain (Spaemann 1993, 154; Spaeman 2011b). ${ }^{4}$

Pleasure and pain are properties and states that contain a focus and, a so-called vector. Pain, therefore, in a creature that is sensitive to it, determines its behaviour aimed at freeing itself from this unpleasant sensation. This is why, one must not inflict pain on animals, without a serious reason, especially severe pain (Spaeman 2011b).

As it has already been stated, an animal is a living being. Like any being of this kind, it is a carrier of the inner sphere, the existence of which is possible to prove. After all, the animal possesses wishes, experiences various pain, expresses its joy, reveals fear, etc. By virtue of this fact, it does not turn out to be an object. Here, it becomes understandable, why a practice, or a custom, according to which, each animal, even within a large herd, has its own name and its owner addresses it personally, arouses sympathy. It expresses nothing more than an accurate perception of what an animal is. It is not reduced to the rank of an object; it appears as an individual. Therefore, one of the French shepherds, known to Spaemann, who took care of a large flock of sheep, could say in his heartfelt statement: I do not want to have more sheep than those I know by name. ${ }^{5}$

An animal reveals its inner life, which is a manifestation of a sensual soul. According to the accurate statement of Thomas

1960: 298). As Aristotle argues, animals, like plants, possess a vegetative soul. However, it is only thanks to their sensory soul that they are animals (Arystotels 1979, 736b).

${ }^{4}$ As Aristotle points out - "A being, that has a sense, also experiences pleasure and pain, and consistently discerns objects, that bring pleasure and inflict pain" (Arystoteles 1972, 414b).

${ }^{5}$ Quoting the above opinion, Spaemann also praises the custom of the peasants from the past, which required them to address each of their animals by its name (Spaemann 2011b).
Nagel, we will never know what it is like to be a bat. ${ }^{6}$ Similarly, we will not know, what it means to be any other animal (e.g. a cat). After all, we can notice that a specific animal, e.g. a cat, is not only an object that we can see but that it also sees us, and that behind this gaze there is always a hidden mystery which only reveals itself in this gaze (Spaemann 2000, 472). We cannot enter into the feelings of an animal that will always remain a mystery to us (Kożuchowski 2006, 90; Spaemann 2011b) for this reason.

Cardinal John Newman might have said that an angel is more understandable to us than an animal. Angels are rational beings, and for us, based on thinking and reason, we can communicate with them, or at least imagine, what it means to be an angel. Animals, on the other hand, have their own subjectivity (that is, they are not objects and we need to see their inner life since they experience various mental states), which will always be hidden from us (Kożuchowski 2006, 90; Spaemann 2011b).

Due to the above facts, the deep meaning is revealed by behaviour that is surprising to us, of the archaic hunting cultures, such as, for example, gestures of asking for forgiveness. After all, there is a symbolic recognition in them that the existence of an animal is, to say the least, inbred Selbstsein.

We also talk to animals in our language, namely the one with grammar that is not available to them. However, as a result of such references, we are closer to the truth than those who treat them as objects (Spaemann 1993, 229).

Naturally, there is an irreducible significant difference between a man and an animal. From an ontological point of view, what distinguishes an animal from a human being, is that it is devoid of a spiritual soul (Gilson 1960, 298; Spaemann 2011b).

In his reflections, Spaemann emphasizes, that an animal's inferiority to a man is

${ }^{6}$ A similar position is taken by one of the most prominent contemporary German anthropologists, Helmuth Plessner, because, as he points out - "We can never know what an animal really feels, what it experiences as a motive, and what as a stimulus, when it behaves in a certain way" (Plessner 1988, 232). 
marked in two ways. Firstly, a man is superior to animals thanks to his intelligence and the ability to free himself from the pressure of instincts. This last skill proves that we, as humans, are in many respects free, which cannot be said of sensual beings. After all, we can, for years, distance ourselves from useful values, the field of lust, the need to eat and drink, and not be guided by compulsion in the sexual field, which animals are subject to, what can be shown with an example of their behaviour in the time of oestrus. The second kind of human superiority over animals appears as an ability of a relativization one's point of view, that is, the ability to put in the centre of references and interests not oneself but the other being (Spaemann 2000, 471). Speaking the language of Plessner, it means, a specific human way of being in the world, which he describes as an eccentric positioning (Plessner 1988, 240). This skill manifests itself, among other things, in abandoning the pursuit of something beneficial, (which we care about very much), simply because, it would cause harm or hurt another being. An animal, such as a cat, would not have done such a thing for it does not know, what a mouse, it is playing on, feels (Spaemann 2000, 471) ${ }^{7}$.

\section{Do animals have rights? \\ Obligations towards animals}

On the ground of, the so-called ecological theory, attempts to prove that human beings, but also animals, are entitled to moral status and rights (Ingesiep, and Baranzke 2008, 79-81; Vardy, and Grosch 1995, 192-193; Czarnecki 2008, 217). Spaemann confirms that modern advocates of this view say nothing new regarding the talents of animals than St. Thomas Aquinas had said when they mention as characteristic: emotional experience, sensitivity to pain and suffering, a specific purposefulness to preserve (Tomasz z Akwinu 1998, 292-302; Ślipko 2009, 68; Spaemann 2011b). How-

${ }^{7}$ As Plessner also points out: "When chaos arises, when panic erupts, in extreme social situations, reactions are resulting from mutual emotional arousal, reactions that are not different to those of animals" (Plessner 1998, 238). ever, their point of view on animal rights must be regarded as a misunderstanding. ${ }^{8}$ Although not because it is impossible to demonstrate rationality in creatures defined as sensual, even in the elementary sense. The behaviour of superior animals and their ability indicate, that they possess what might be called practical intelligence. They solve problems, they can get out of a difficult situation. On the other hand, they do not possess a mind in the sense of self-awareness and cannot think independently of the circumstances. So, they "think" only in connection with a specific situation and are not able, like us, distance themselves from reality and reflect (Spaemann 2011b).

It must be emphasized that relations of the nature of laws occur only among beings who are persons and are endowed with self-awareness, Therefore, animals cannot be subject to the laws. Not being able to reflect, they do not have the awareness of them. Consequently, they are unable to distinguish between eligible and ineligible requirements. And it is impossible to explain to those beings, for example, in case of giving them pain, a purpose of it. For this reason, they cannot be burdened with requirements in the sense that people are. The latter create those requirements, expecting others to accept them (Spaemann 2000, 471). ${ }^{9}$ Animals are completely dependent on their surroundings because they cannot even imagine the concept of laws. Therefore, it can be said that they must be completely indifferent to the issue of being a subject of law and that it cannot be of interest to them at all. It confirms that they cannot enter into legal relationships.

The issue of rights and obligations does not appear to be symmetric. You cannot express yourself the way: because animals

\footnotetext{
${ }^{8}$ This is the way because, among other things, it precludes our natural right to kill an animal even for a legitimate reason. After all, it is not the very fact of the deprivation of life that is the problem, but only how we relate to this being.

${ }^{9}$ An animal is also not capable of taking on duties, because it is not able to come out of its centricity (that is, placing itself, and not another being, in the centre of attention) (Spaemann 1993, 155).
} 
have rights, we have obligations. For we should think like this: animals have no rights, but we are not exempt from our duty towards them.

For we have responsibilities towards those beings. A man should guard their welfare because he is a person, he shows an aptitude for self-reference, that is, placing in the centre of attention, not oneself, but another being (Spaemann 1993, 470472). He is therefore supposed to remove all threats from animals, not because they have rights. Such behaviour results from his dignity and belongs to it. He only confirms it by the fact that he cares for the beings, inferior to him because the gift to do it comes out from his own dignity. If, as the Bible says, he was given power over nature, then this sovereignty should be revealed not as the rule of a tyrant, but a king fulfilling his duties towards animals because of self-esteem. This fact, therefore, indeed obliges him and he must not treat lawlessly a being inferior to him.

Unfortunately, people often misunderstand the above. Due to the fact that animals are not subject to the law, people think, that they can treat them the way they want to. However, it is impossible to agree with such a view. We are responsible for those beings, especially for the ones that we have tamed and are subject to our care (Spaemann 1993, 230-232; Spaemann 2011a).

\section{Experiments on animals}

The following should be taken into account in case of such experiences. Yes, medical interests justify painful experiments on animals, but only because they aim to save people's lives or avoid suffering. After all, for the sake of human welfare, surgeries associated with pain are performed. Because of its benefit, animals can be subjected to surgery, but with anaesthesia, so as not to inflict unbearable pain on them.

Also, understandable and legitimate are the experiences of those creatures, which have direct value for scientific and medical progress, and the sufferings inflicted during them do not turn out to be too strong. This matter is under the care of ethical committees, which interfere with the procedures of the experiments (e.g. with monkeys) and ensure that the limits are not exceeded and that it is not done against the nature of the animal (Spaemann 2000, 474; Spaeman 2011a).

However, animal experiments carried out due to the needs of the cosmetics industry should be considered unacceptable. Let us note what action they dictate in case of those creatures, e.g. hare. Well, certain drops are poured into their eyes, and it is observed whether it will completely destroy the eyes or it will cause pain and suffering. A definite "no" to such practices is even more justified, as we have a sufficient number of cosmetic products to beautify women's eyes and there is no need to produce more types of them. There is no need to satisfy the tastes of the new fashion regarding the aesthetics of the organs of the sense of sight since its price is an unnecessary nightmare of the suffering of defenceless beings (blinding the hare) (Spaemann 2000, 473; Spaemann 2011a; Vardy, and Grosch 1995, 192-193).

Experiments to demonstrate that certain drugs (e.g. tobacco products) are harmless and provide pleasure. After all, paying with heavy suffering of animals for this kind of pleasure (the achievement of which those experiments were supposed to ensure) defies human dignity. There is a hint that this is the case. It is the way and the shade of a reaction to the very thought of the pleasure possibly obtained in this way. Well, any normally sensitive person would consider it poisonous, if only they could see the consequences of enjoying it. This would only be possible if the price of this pleasure was hidden.

With those kinds of experiments, every effort should be made to find alternative routes, including, e.g. drug testing, experiments on fresh and still somehow living meat of animals, as soon as they are killed, and all other possible actions that do not cause the suffering of those creatures (Spaemann 2000, 474-475; Spaemann 2011a). According to the results of psychological and sociological research, it turns out that 
such efforts are not sufficiently undertaken unless the practice is clearly shown as a temporarily tolerated provisional. For as long as new, great institutions and other structures are built and workplaces are established for animal experiments, they will still be used as victims for such experiments (Spaemann 2000, 474). According to Spaemann, there should be a significant reduction in the institutions involved in conducting scientific experiments on animals (Spaemann 2011a). For any means, perpetuating such practices are incompatible with a far-reaching, determined effort to eliminate them.

Finally, new criteria must be established to determine the unavoidable degree of suffering of animals, so that (as Spaemann points out) their existence, so to say, as only a pain, would not define an important part of their lives. The experience of suffering is always subjective and appears as the dark side of fate. Therefore, deliberate causing it, despite the benefits it is supposed to bring, is incompatible with the idea of human dignity (Spaemann 2000, 474).

\section{The issue of hunting}

In the ethical discussion about animals, another important aspect is the question of hunting (Vardy 1995, 193). What is its ethos like, when it is undertaken only for the sake of fun and entertainment? Of course, killing only for the sake of killing would be a meaningless and immoral act. If it is an indispensable activity, then there is nothing wrong with the fact that one hunts willingly and with a feeling of pleasure, even passion. It would be incomprehensible to show dissatisfaction and bad humour in an activity that, from an ethical point of view, is justified and right for four reasons. It, therefore, appears as a necessity when there are too many animals (roe deer, deer, foxes, etc.) in a forest, the number of which must be reduced due to the serious damage it causes (the first reason). It is an incomparably better solution than slaughter (reason two). An animal does not have to experience horror and agonizing fear that they experience in the slaugh- terhouse at the sight of living creatures of their own species being killed.

Let us add that also transport, e.g. railway, to the above place triggers great stress in them, because they sense what their fate will be. For this reason, the practice of killing cows on pasture with the use of an appropriate apparatus, which is already done by some German farmers, should be regarded as worthy of the highest praise, since the animals do not manage to find out the intention of their owners. It is hunting that must be preferred to slaughter for the following, third, reason. Slaughter turns out to be worse for an animal, even compared to fighting during corrida, although the latter practice is also problematic. For it causes a real torment. This act means a long process of killing an animal and its pain and suffering are multiplied by the fact that it is completely dependent on the environment and powerless. This process begins with transport to the slaughterhouse in very crowded wagons. The animal painfully senses and experiences its final moments when it finds itself in such a place. At the very sight of blood, it reacts with fear and panic. It is also killed during corrida. In the combat of this kind, however, it feels itself, defends itself, enjoys freedom, and has freedom of movement (Spaemann 2001, 140; Spaemann 2011a).

Hunting is still a necessity because of the interest of a man because it provides him with food (reason four), and it is even necessary for survival (Vardy, and Grosch 1995, 193; Spaemann 2011a). Finally, there is a pragmatic reason for hunting. Meat obtained from animals this way is tastier than from slaughter because great stress has a negative impact on its quality (Spaemann 2011a).

\section{The issue of breeding and the phenomenon of vegetarianism}

Animal breeding obliges us to provide them with decent living conditions appropriate to their nature. This assumes that they will not be deprived of their ability to meet their basic needs. This includes not only feeding with the right fodder, but 
also the opportunity to move freely, dig in the ground, not live in a cramped and dark but a large and bright room. The animals' interests must be taken into account in breeding (i.e. their needs and desires), not exclusively the ones of a man (Spaemann 2011a; Slipko 2009, 60). Meanwhile, some of the ways of breeding are more cruel for a bull than ending its life during corrida (Spaemann 1993, 229). This happens, among other things, when they put on weight too quickly (up to 400-500 $\mathrm{kg}$ in three months), which is an unimaginably great torment for the animals. ${ }^{10}$ It also happens for example, in places where hens have no freedom of movement, bulls are fed with liquid food in a lying position, and calves are not fed with natural green fodder, which weakens them so much that they cannot stand on their own feet.

The bright colour of the meat of those animals reveals a disease that is a consequence of the type of food (Spaemann 2011a). The widespread mass-breeding method should therefore be called nothing other than a wicked practice. So, vegetarianism becomes an understandable fashion. After all, it is often based on a protest against the observed acts of tormenting animals. Of course, vegetarianism alone does not oblige us morally. Nor does it guarantee to be ethically impeccable. Hitler, as we know, was a vegetarian. After all, vegetarianism itself is not a bad thing. Therefore, we do not have to be vegetarians, but we can be vegetarians if we want to (Spaemann).

\section{Responsibility for species}

As Spaemann points out, our duty towards plants and animals relates to the existence of species, not individuals. This means that we are allowed to kill (taking into account, of course, the way we do it) individual representatives of those beings, but we are not allowed to destroy the entire species. Why? The diversity of species reveals not

${ }^{10}$ According to Professor Bertthold Wald, in Ludinghausen, a large farm where 4,000 pigs are raised, in the tightest possible room, which they can never leave and are not able to move inside it because each of them must be of such weight, after 90 days of breeding. only the richness, beauty and well-being of this world, the magnificence of its Creator, but it is also an indispensable condition for global ecological balance. ${ }^{11}$

Unfortunately, modern farming methods have killed a large number of animals and caused the extinction of many species. This phenomenon must be very worrying and alarming. Admittedly, species also died out in the past, but at a much slower pace and not as large. Nowadays, however, almost every year a significant part of them disappears, and the existence of, for example, tigers in China, fish and birds is particularly threatened (Spaemann 2011a). To what extent this fact burdens conscience of modern humanity. It is no different than the sin against future generations, which cannot be justified by anything.

Yes, it is not our responsibility to plan their happiness. After all, we should pass on to them the natural richness of reality in undiminished amount, since we have used its fruits all our lives. A civilisation that does not strive to meet this imperative becomes similar to the world of parasites and is doomed to share its fate. Because of its parasitic existence, it will lead to self-destruction. Thus, a strong utilitarian argument may be put forward against such a civilization. It takes into account the consequences of the disrespectful reference of this civilization (its self-destruction) to future generations because it squanders the good contained in nature (Spaemann 2000, 473).

\section{Animal suffering and the question of responsibility}

According to experts, sensitivity to pain and suffering is a particularly pressing issue in the field concerning those creatures. Meanwhile, also in contemporary philosophy, one can list thinkers, who question this kind of attribute of the animal world. ${ }^{12} \mathrm{Ob}$ viously, the position of those thinkers must be considered as peculiar and surprising.

${ }^{11}$ As Ferdinand Krenzer points out, the diversity of animal and plant species is a reflection of greatness of God (Krenzer 2000, 262-263).

12 Among philosophers questioning the ability of animals to experience pain, the author of the article cite A. Dennett (2005), Harrison (1991). 
One has to be, as Spaemann points out, blind to not notice that an animal is suffering. Therefore, the German law states: "No one, without a reasonable cause, is allowed to inflict pain, suffering or harm upon an animal." Unfortunately, there is too much pain and suffering in the animal world for four reasons: breeding methods and living conditions that are contrary to the nature of animals, problematic experiments (especially when their primary purpose is economic and research, not the welfare of animals), slaughter. There is also an interference with nature, which should be emphasized separately, i.e. genetic manipulation. This means that an animal is bred not to live, but for laboratory purposes only. Meanwhile, those are the worst of the interference, as the animal suffers not as a result of illness or external pain. It is condemned to it by a virtue of a natural endowment with which it was born (Spaemann 1993, 230; Spaemann 2011a). Those interventions are devoid of shame. They lack what has been synonymous with morality since Greek times: shame, fear, aidos (Spaemann 1993, 230).

As it has already been stated, inflicting pain and suffering on a creature that is vulnerable to it, such as an animal, requires justification (a reasonable cause). Pain contains an appeal to avoid it (Spaemann 1979, 9). For this reason, animals should not be exposed to it, especially when it causes great suffering. As Spaemann points out, they cannot incorporate their suffering into the higher identity of the conscious context (that is, make sense of it) and thus control it. As a result, they are completely doomed to it. This way, the suffering they experience becomes something particularly severe, because pain is, to say the least, only pain, especially when they cannot respond to it with aggression or escape (Spaemann 2000, 472).

Meanwhile, a man experiences suffering in various ways; is able to approach to it as to something necessary. He appreciates the time in which he was spared. At the same time, being a believer, he is ready to receive pain from the hand of God, to take part in Christ's suffering. The non-believer also faces it more or less bravely. Meanwhile, the animal simply suffers, because it does not see the purpose of its torment (Spaemann 2011a). The issue of animal suffering is closely related to the question of responsiveness. One can list two types of it, i.e. responsibility towards those entities and responsibility for them.

\subsection{Suffering and responsibility towards animals. The problem of tormenting them}

We are not responsible towards those living creatures. We owe it only to those who can ask "why?" and "based on what law" or "for whom?" something can be good or bad. However, we are unable to give animals a possibility to decide here. This suffering is necessary and must be accepted, and that one is too big and we cannot cause it, or are not allowed to cause it such a persuasion has no raison d'être. An animal is not able to judge what is fair and what is not; after all, it is not endowed with a sense of righteousness. For this reason, we are not responsible towards them. Instead, we are responsible towards God, to whom we must report our attitude towards the creatures of the inferior species.

It is also important to emphasise the consequences that it can leave behind in relation to other people, our attitude towards animals, which is irresponsible and manifests itself in the torment of those creatures. As Spaemann recalls, it was already in his childhood, that he learnt from the Catechism, that animals should not be unreasonably suffering. In the light of the Catholic doctrine, those who treat animals harshly also treat people inappropriately, or in other words, we become inferior to humans if we mistreat an animal. Why is it so? It would not be the case if animals and humans were unrelated to each other. But in fact, they are. Therefore, this is the case. Of course, it should be stated that there is no close interdependence in this respect. Some people respect their fellow human beings and, at the same time, show a lack of respect towards animals. In fact, a situation of the opposite kind can occur, 
to recall, for example, Hitler, who was an animal lover. In any case, as Spaemann concludes, in the doctrine of the church, animal cruelty has always been considered as evil (Spaemann 2011b).

\subsection{Suffering and responsibility for animals}

As Spaemann points out, not towards animals, but for them, we are responsible, which is particularly evident in the problem of suffering. After all, we are not responsible for every pain and not for every animal", he said. How far our power of action riches (our capabilities), that far our responsibility for the beings of a sensual nature reaches. We are primarily responsible for the animals which we have tamed and are dependent on us (Spaemann 1993, 61). Treating them as ordinary objects forbids us to respect ourselves, and contradicts our claim that we should be seen as superior to them.

We are responsible, in the slightest extent, for the suffering of animals in case of them being killed. The act of depriving those beings of their lives is only inappropriate if it is carried out without necessity or a justified reason. ${ }^{13}$ Normally, it cannot be something shameful for two reasons an animal, just as every living being - excluding people - is not an absolute goal for itself. The destruction of such kind of life is part of the processes of nature; no animal can survive without destroying another life (Spaemann 1979, 9).

Contrary to what some argue (reason two), its interior does not integrate life in the form of a biographical unity. ${ }^{14}$ It cannot be said that it consciously pursues the goal of its life, evaluates its actions. ${ }^{15}$ On the

\footnotetext{
${ }^{13}$ If we are unable to provide care for an animal (a dog) we are allowed to kill it.

14 In other words, the animal has no reference to itself, in the sense of being aware of the totality of being and the connection of individual states into a timeless identity (Spaemann 2000, 472).

${ }^{15}$ According to, for instance, a Swedish bioethicist, Anders Nordgren, certain animals, such as mice, rhesus are entities of biographical life, not just biological. The biographical life includes history, actions, relations (Nordgren 2008, 425). After all, it is difficult to agree that history exists there, in the lives of those animals. It is, after all, a conscious and free
}

contrary, it lives from a moment to a moment and is not able to do so differently. An animal cannot awake into reality and existence. As a result, it is not familiar with the meaning of being and of not being, but only with the opposite of being as such and being different Sosein. Anderssein - an animal, distinguishes only between what is pleasant and unpleasant and between factors like green and red. Therefore, the responsibility for animals refers to "their" life, not to existence as such (Spaemann 1993, 231).

To what extent can preventing human suffering justify inflicting suffering on animals? The question is indeed complex in many ways. There are, therefore, such degrees of animal suffering that we should never, for any reason, inflict on a living being. To determine this degree, one must also consider the length of pain in proportion to the length and lifestyle of the animal (Spaemann 1993, 231). So, if an animal born in a cage or somewhere else is used only for experimental purposes, and it soon dies, it means that its whole life is actually about suffering and being hurt. Such a situation should not, however, take place because life has a different meaning, other than the experience of suffering and only painful experiences.

The situation is different, in the case of people affected by severe suffering. Then experiments on animals are permitted, causing the suffering of those creatures. Also, painful experiments can take place when their purpose, as Spaemann points out, is to protect beautiful eyes from suffering (Spaemann 2011a). Similarly, not every increase in the welfare of human life justifies all suffering of animals without exception. This involves testing (using chemical agents) on the eyes of a hare, so-called beauty drops, causing total destruction of eye receptors of those animals. It is an immoral act (Spaemann 2000, 469).

action. At most, animals have their history understood as past events (because they live in time), and thus do not create it. While a man creates it because he/she acts deliberately and purposefully. Similarly, not an action itself, but a conscious action, can be considered as part of a biography. 


\section{Conclusion: animal protection and human dignity}

A slogan "animal protection is human protection" does not appear to be false, but superficial. It is not self-interest, but self-respect that dictates us to allow animals to live, short or long, according to their specific nature, without inflicting great pain on them (Spaemann 2000, 471). It is not, however, a consideration of the benefits, even of the fundamental nature of the goods, that animals supply us with, (e.g. food, medicine) that would ultimately motivate us to care for them? In such a case, a significant reduction of the number of species would probably be justified (Spaemann 1993, 231-232).

After all, human dignity has its source, talent and aspirations, which allow us to do justice to its own essence. With reference to animals, it will be expressed in the treatment that is truthful about them. So, it will not allow us to refer to those beings, as if they were a kind of resource of a purely useful feature. Naturally, we can also look at them from this point of view, which is to make use of them. But we must not limit ourselves to such an approach. An animal possesses a wealth that is disproportionate to the sphere of useful values. As Spaemann rightly points out, it has an inner world (Spaemann 2000, 472-473). An object, such as a car, which is within our range, does not perceive or look at a person. While an animal does so.

Therefore, our respect towards ourselves dictates that we refer to animals in harmony with their nature and respect their nature. In doing so, it designates behaviour that is compatible with our dignity. It is in that, where a man's ability to care and be responsible for nature, especially for animals, is based. Because a man has his dignity, expressed in the ability to relativise his own point of view (making the primary object of concern not himself, but another being), he can help animals and look after them and contribute to the realization of their existence according to their essence. We can better understand the deep meaning of the biblical saying: "all nature is under his rule". In other words, a human dignity manifests itself, not only in the abandonment of the expansionist and despotic attitude, typical of a tyrant. It is expressed primarily in a contemplative reference to the animal world, with respect. It allows, on the one hand, to see the inner, ontic richness of the world - its beauty, its goodness (for dignity, as Goethe notices, is the ability to worship not only those superior to us, but also those inferior us), and on the other hand, to experience the joy from this fact and to be happy about it. Therefore, the experience of sadness occurs as a result of the perception of phenomena that do not have material repercussions. And it happens because of the news itself, for example, about dying or extinction of other animal species. By wishing to protect their world for the sake of joy or sorrow, it means that this attitude is motivated by nothing but appreciation. As Kant points out, appreciation coming out of beauty is a disinterested appreciation. It is confirmed here that concern for this world cannot be explained by considerations calculated to meet one's own needs (Spaemann 2000, 471-473; Spaemann 1993, 231-232). Rather, it is the property of a rational being, that it may have an interest in something that does not bring him anything (Spaemann 1993, 231-232).

\section{Bibliography}

Arystoteles. 1972. O duszy. Warszawa: Wydawnictwo Naukowe PWN.

Arystoteles. 1979. O rodzeniu się zwierząt. Warszawa: Wydawnictwo Naukowe PWN.

Czarnecki, Paweł. 2008. Dylematy etyczne wspótczesności. Warszawa: Centrum Doradztwa i Informacji Difin.

Gilson, Étienne. 1960. Tomizm. Warszawa: Instytut Wydawniczy PAX.

Ingesiep, Hans W., und Heike Baranzke. 2008. Das Tier. Stuttgart: Reclam Verlag.

Kożuchowski, Józef. 2006. Spór o człowieka we wspótczesnej filozofii niemieckiej. Pelplin: Wydawnictwo Bernardinum.

Krąpiec, Mieczysław A. 1996. „Byt materialny żyjący. Niektóre aspekty filozofii przyrody." W Wprowadzenie do filozofii, red. Mieczy- 
sław A. Krąpiec, Stanisław Kamiński, Zofia Zdybicka, Andrzej Maryniarczyk, i Piotr Jaroszyński, 229-267. Lublin: Redakcja Wydawnictw Katolickiego Uniwersytetu Lubelskiego.

Krenzer, Ferdinand. 2000. Morgen wird man wieder glauber. Limburg: Lahn-Verlag.

Nordgren, Anders. 2008. „Eksperymenty na zwierzętach a teoria ewolucji." W Wiedza o etyce, red. Jan Woleński, i Jan Hartman, 418-431. Warszawa-Bielsko-Biała: Wydawnictwo Szkolne PWN.

Plessner, Helmuth. 1988. Pytanie o conditio humana. Warszawa: Państwowy Instytut Wydawniczy.

Spaemann, Robert. 1979. Gut und Böse - relativ? Freiburg: IBK.

Spaemann, Robert. 1993. Glück und Wohlwollen: Versuch über Ethik. Stuttgart: Klett-Cotta. Spaemann, Robert. 2000. Grenzen. Stuttgart: Klett-Cotta.
Spaemann, Robert. 2001. Osoby. Warszawa: Oficyna Naukowa.

Spaemann, Robert. 2011a. Józef Kożuchowski interviews: Professor Robert Spaemann (Stuttgart, 28 Feb 2011). The recording of the interview is available in the personal archive of Józef Kożuchowski.

Spaemann, Robert. 2011b. Józef Kożuchowski interviews: Professor Robert Spaemann (Stuttgart, 02 Mar 2011). The recording of the interview is available in the personal archive of Józef Kożuchowski.

Ślipko, Tadeusz. 2009. Bioetyka. Kraków: Wydawnictwo Petrus.

Tomasz z Akwinu. 1985. Suma Teologiczna, vol. 13. Prawo. Londyn: Katolicki Ośrodek Wydawniczy VERITAS.

Tomasz z Akwinu. 1998. Kwestie dyskutowane o prawdzie, vol. 2. Kęty: Antyk.

Vardy, Peter, i Paul Grosch. 1995. Etyka. Poznań: Zysk i S-ka Wydawnictwo. 